Advances in Social Science, Education and Humanities Research, volume 136

2nd International Conference on Social and Political Development (ICOSOP 2017)

\title{
Resilience of Women Leaders as Village Heads in Patriarchal Culture
}

\author{
(Eco-feminist Analysis)
}

\author{
Harmona Daulay, T.Ilham Saladin \\ Sociology Lecturer in Faculty of social and political sciences - USU \\ email:harmonadaulay@usu.ac.id
}

\begin{abstract}
This study analyzes the issues that arise from the facts of women as leaders. The fact does not necessarily dissolve the perception of most of the people in Indonesia leaders in government and in other public sectors are men. Data in the Batu Bara District civil servants of women more than men, plus there are 10 female village heads. There are interesting things in the phenomenon of women's leadership in Karang Baru Village, Talawi Sub-district, Batubara District, where from Head of Village a woman, also other village apparatus dominated by women. Analysis of this paper will uncover the reason for being a leader and selecting village officials under his leadership who are also women. How does the style of women as leaders take advantage of the femininity that has been considered weak into a force as a leader of women? The informants of this study were female and male villages heads, This research uses the qualitative method, data obtained through in-depth interview and focus group discussion. The results of the study found Stereotype femininity with the term fussy, meticulous and can perform various jobs (multi-tasking) to make the village head's mother's strength in running the village government.
\end{abstract}

Keywords: Female leader, eco-feminist, and patriarchy

\section{BACKGROUND}

Most people in Indonesia assume that leaders in government and other public sectors are men. Whereas in fact, many women leaders became the phenomenon of leadership in Indonesia in these two decades. We can see in the context of President Megawati who led the period from 2001 to 2004. The ministers in the government cabinet of Joko Widodo in Indonesia where there are 8 women ministers who lead the ministry. The phenomenon of at least female leaders is not only in government but also in the business and private sectors. Data showing gender discrimination is still experienced by Indonesian women in high-profile positions in business and private firms McKinsey and Femina's survey of 500 working women occupying junior managers, executives, and CEO positions across Indonesia disclosed the fact that 47 percent half of the graduate respondents were able to hold positions at entry level. While at the middle management level, the share of women is decreasing and only remaining 20 percent. This amount is getting smaller at the level of directors, which is 6 percent at the level of directors and 5 percent in the position of CEO. (Kompas, 2012) within. (Zabrina and Setiawan).
The increase in the number of women in charge of the regions is seen in the interim recapitulation, of 123 candidates for heads and deputy heads of women in 2015, at least 35 candidates are elected, "said Peritiem Executive Director of Titi Anggraini on Rappler, Thursday, December 10th. This quantity becomes an exciting thing in the dynamics of the study of women leaders.

Moving from the data and conditions of women leaders on a national scale, There is an interest in women's studies in local politics in North Sumatra. The phenomenon of women who lead at the local level as in districts and cities in Indonesia is quite a significant improvement. It is also interesting when women leaders emerge in the context of a village area.

As is the case with many female village heads who emerged as leaders in Indonesian society. The fact in Karang Baru Village in Talawi Sub-district Batubara Regency is a unique phenomenon. In this village, the women who lead not only as village head but also village officials are held by women, such as village secretaries and other village officials. The research is expected to explain what is the reason for the village head's mother to become a leader and why choose village officials under his leadership who are also women. How does the style of women as leaders make use 
of the feminine side that becomes a force in the potential of women?

\section{THEORETICAL FRAMEWORK}

\begin{abstract}
According to Karlis (1996), generally Americans believe women's employment opportunities are not the same, but they prefer to be led by male bosses rather than women. In the literature review above shows that women's leadership portraits are still on the feminine leadership style, yet many women are entering leaders at senior management level, as well as very few women entering top management. Based on this, research on women leaders in top management from village level is important to know.
\end{abstract}

There are four styles of women's leadership, firstly, a masculine leadership style which accentuates power. Second, the feminine leadership style is characterized by being a caretaker for others and responsible for the activity. Third, the transactional leadership style, that is, the more exchanged relationships The four styles of transformational leadership, the leadership style of change is better.

This paper will use feminist theory in raising gender issues in women's leadership. The word "eco" in ecology comes from the Greek Oikos, which means the home of all women and men, animals, plants, water, soil, air, and sun. The theory of ecofeminism is assumed to see individuals more comprehensively, ie as being bound and interacting with their environment. At the beginning of the concept, ecofeminism looks at the issues of women in participation with the natural environment around.

The interesting thing about this ecofeminist study is the criticism of what happens in women's emancipation is that when women enter the masculine world once dominated by men it no longer accentuates its feminine qualities, but instead becomes a male clone and entering into a hierarchical masculine system trap. The inclusion of women into the masculine world (the public world generally) has led to a more dominant modern civilization colored by masculine qualities. Consequently, what is seen is competition, selfcentered, domination, and exploitation. The real examples of the fading mirrors of feminine quality (love, nurturance, and nurturance) in society are the increasing destruction of nature, the rising of crime, the decline of social solidarity, and the increasing number of women who abandon their children.

This is the relevant ecofeminist note in the context of this study. How does the village head's mother make various approaches in leading the community? The approach is done by practicing the value of femininity. The value of femininity as women more concerned, more detail, neater.

\section{RESEARCH METHOD}

This research uses qualitative research method. The research corpus is the female village head and female village apparatus and the head of the PKK and other women's tools. Informant research amounted to 10 people. Data collection was conducted through interviews with key informants and additional informants. In addition to the interviews also conducted focus group discussion to complement the lack of existing data.

\section{RESULTS AND DISCUSSION}

4. 1. General Overview of Karang Baru Village, Petatal Sub-District, Batubara Regency

Batubara Regency is one of the regencies in North Sumatera Province that was formed in 2007, which is an expansion of Asahan regency. Coal is located on the East Coast of North Sumatra region bordering the Straits of Malacca. Batubara Regency occupies an area of 90,496 hectares consisting of 7 districts and 100 villages.

Karang Baru Village is one of the villages among nineteen villages and one village in Talawi District of Coal Regency. The village of Karang Baru was formed on the 19th of Apri 1994, the result of the division of the village, namely the split from Petatal Village. The total population of the village of Karang Baru Talawi Sub-district of Batubara Regency is 2,782 people, consisting of 747 families. The male population is 1,331 inhabitants, and the female population is 2,782 inhabitants. From the monograph data, it appears that the number of female population is more than the number of male population. 


\subsection{Women's Role in Village Leadership}

Karang Baru Village in Talawi Sub-district Batubara Regency is a village surrounded by oil palm plantations. The social system of the plantation community greatly influences the daily life of the people. The dominance of the Javanese tribe became the reference to life and tradition in this region. Within a decade the leadership of the village head was led by a woman. The village employees also consist of 6 people as well as women. The number of hamlet heads as many as 6 people. The thing that attracts the hamlet heads are all male. Harmonious working relationships with female village heads with female village apparatuses as well as male heads of men are seen to show the performance of this village. This is evident from the use of village budget funds (ABD) examined and a role model for other nearby villages.

The leader of the village of Karang Baru named SA mother and he has led for two periods, namely from 2006-2012 and 2012-2018 period. He in the eyes of the village officials considered very wise to carry out leadership. Before becoming a village head he was a teacher and was actively involved in community activities. He is the wife of the head of Karang Baru Village before. The key to his victory is the number of women's votes who chose him. Women voters are also very gender biased because they choose SA's mother because she is a woman. As one of the informants of village women's informants stated that:

"because if the woman is more carefully so, more concerned with the community so. Another guy with a man. If it's a man, just what's okay if someone is reporting it is up to where it's good. If women are more deeply into the problems in this village. (Eva Village Employees Interview)"

The headmaster of the SA village also chose the village apparatus, the village secretary in the village office as well as a woman. Other village apparatuses are head of affairs and other devices are women. The number of village units as many as 6 people indeed in the shake by women. The reason SA mother chose women's devices because they are considered to have the appropriate competence.
The Hamlet head consisting of six hamlets is led by men. It is related men are more suited to work in the field. In addition to this, the hamlet chiefs also admitted that they lack skills in the administrative world. This is as stated by the head of Hamlet B which states :

"if we feel that we are not harmed and we accept Mrs., and there is a division of labor that woman is office and its man in the field and until now we enjoy more field work that directly comes into contact with society".

From the above statement shows there is a division of labor between female employees in the village office and the male kids in the area (field). This shows the willingness of hamlet heads who feel they have no computer skills and other administrative skills. So that the placement of women in the appropriate place with the ability to be precise.

In the study of leadership patterns when we associate with some theory of leadership type then its direction to the feminine style mixed with the transformational style. This is related to the emphasis on the sense of motherhood as well as highlight the femininity like the concept of nurturing which is played by SA mother. Maternal roles such as playing an active role in social activities such as in the event of death where when the body of women, SA mother directly into the body of his body.

\section{WOMEN'S LEADERSHIP STYLE IN ECOFEMINISM ANALYSIS}

Women's leadership style in the context of local governance in Karang Baru Village is important to be analyzed related to how SA mother perform various duties in performing the role as to village. The challenge of leading the village with about $48 \%$ of men is a challenge. In the SA leadership studies, the leadership approaches the social activities of the mothers and administers village administrations quickly and conducts joint deliberations for the implementation of village finances.

How does this SA mother's leadership relate in the context of feminism? Feminism appears to respond to the problem of gender 
inequality, discrimination, oppression, and violence against women. Feminism and ecological movements have mutually reinforcing goals, both of which are about building a view of the world and practices that are not based on models of domination (Darmawati, 2002, 16). In a further study, the goal of ecofeminism ethics is to build at least theories and practices that pay attention to human and non-biased environmental environments. (Waren, 1996, xi). Ecofeminism at first did speak how women are close to nature and the natural world is played as women (Halkes, 1991).

How women's study in local village politics can be linked to ecofeminism. This relates to a mother in the village of Karang Baru as a political symbol and a mother who protects the community. Ecophysists agree that in order to take on male gender-biased roles it is not necessary that women should be equal to men. feminine roles in which the mother is considered to have various powers such as nurturing, caring, more responsive and meticulous to be an important asset to enter the world of local politics by becoming the village head.

The feminist and gender perspective sees that the female lead is weak, whiny, emotional and so forth. It turns out that by the nature of women so it gives positive value in the lead because then the leader was able to understand and understand what happened in the community, more sensitive and sensitive so that will be even stronger to lead. Mrs. SA used this side as a capital to lead the community.

In the stereotype of women who are full of emotional sides, it turns out the stereotype that women better carry out various financial handling. This is related to women as economic managers in the household. This continues also in other public sectors when women are considered better and deft to take care of village funds, mosque funds and so on. As revealed by informant $\mathrm{M}$ :

"since the head of our village, we give women a model of society before the village head has not been women it messed up its internal drafting files "
Female stereotypes with various domestic, public and societal roles also make women more effective in using the time to take care of the household. This is as expressed by the informant :

\section{"if his fathers kind of any more right, Wired at 10 o'clock home at 11 ordinary it mom, drop by there drop by here meet a lot of friends if the mothers were coming home Wirid already come home".}

Data and facts show that the stereotypes and the strength of women's femininity turn out to provide capital in leadership in this Karang Baru Village. This is seen with the strength of SA's mother as a leader and can carry out roles so that it can take office for two periods.

\section{CONCLUSION}

The gender stereotype that saw the woman was weak, crybaby, emotional but all this turned out to be a force for female leadership in the village of Karang Baru Talawi Sub-district. The combination of feminine and transformative leadership styles became the key leadership of the village head of Karang Baru's mother SA. The ability of SA's mother to lead the head of his village which all men also show patriarchal culture in the village of Karang Baru has undergone a shift from a thick patriarchal culture to begin growing a sense of equality between men and women.

Ecophysical theories become the key strength that does not make women into the realm of masculine politics into a male clone. Women can even maintain their femininity until it reaches the top position in a village far from national political power. If gender mainstreaming becomes a program of the Indonesian government to realize equality in Indonesia, it appears that this Karang Baru Village can be an example. 


\section{REFERENCES}

Bystydzienski, Jill, 1992, Women Transforming Politic, Bloomington, Indiana University,

Bogdan, Robert dan Steven J. Taylor1985 : Pengantar Metode Penelitian Kualitatif, PenerbitUsaha, Surabaya,

Budiharjo, Miriam, 1992, Dasar - Dasar Ilmu Politik, Jakarta, PT. Gramedia,

Bungin, Burhan, 2007, Metode Kualitatif, Kencana, Jakarta.

Dewi, Machya Astuti, 2009, Potret Anggota Legislatif Perempuan di Provinsi Daerah Istimewa Yogyakarta Antara Misi dan Kapasitas Personal dalam Gender and Politic, Tiara Wacana Yogyakarta

Fakih, Mansour, 1997, Analisis Gender dan Transformasi Sosial, Pustaka Pelajar, Yogyakarta

Febriasih, Happy Budi dkk (edt), 2008, Gender dan Demokrasi, Averroes Press, Malang,

Hadiz, Liza (edt), 2004, Perempuan dalam Wacana Politik Orde Baru, Pilihan Artikel Prisma LP3ES, Jakarta, 2004

Halkes, Chatarina, J.M. 1991, New Creation, (Kentucky Wesminster: Wesminster/John Knox, Press

Hasibuan, Aziarni, 2009 Perempuan Harus Berjuang Makin Gigih, harian Waspada 17 Maret 2009.

Humaidah, Lisa Noor, 2012, Affirmative action dan Dampak Keterlibatan Perempuan: Sebuah Refeksi, Jurnal Perempuan 75.

Isshiki, Yosiko, 2000, Eco Feminism in the 21 Century" dalam In God's Image Vol 9 no 3

Jackson, Stevi dkk, 2009, Pengantar Teori-Teori Feminis Kontemporer, Jalasutra, Yogyakarta, 2009.
Miles, Matthew B dan Michael B. Huberman, 1984 Qualitative Data Analysis: A source of New Methods. Sage Publication, London.

Pambudy, Ninuk Mardiana, 2009. Keputusan MK Meluaskan Jangkauan Ke Luar Zona Aman, Harian Kompas, 30 Maret 2009.

Partini, (2014), Partisipasi Politik Perempuan Dalam Praktik Kewarganegaraan di Indonesia, dalam Jurnal Perempuan Vol. 19, No. 2, Hal 41-43, Yayasan Jurnal Perempuan, Jakarta.

Ricklander, Louise, 1993Women and Politics dalam Jenny Firth - Cozens and Michael A West (eds), Women at Work: Phychological and Organizational Perspective (Philadelphia: Open University Press,

Sarantakos, 1993, Social Research, Meulbourne University Press,

Shanti, Budi, Kuota Perempuan Dalam Parlemen, Jalan Menuju Kesetaraan PolitikJurnal Perempuan No. 19

Scott, A, McEwen, 1986, Women In Industrialization: Examining The Female Marginalisation Thesis. The Journal of Developmen, Studies 22.4

Subono, Nur Iman,, 2003 Perempuan dan Partisipasi Politik, Yayasan Jurnal Perempuan dan The Japan Foundation Indonesia ( JFI), Jakarta

Soejipto, Ani, 2005, Politik Perempuan Bukan Gerhana, Jakarta, PT. Gramedia, Undang Undang Pemilu : Implikasinya Untuk Perempuan,

Surbakti, Ramlan, 1992, Memahami Ilmu Politik. Jakarta, Pt. Gramedia,

Tan, Mely G, 1995, Perempuan Dan Pemberdayaan (Makalah dalam Kongres Ikatan Sosiologi Indonesia (ISI)), Ujung Pandang.

W, Dorothy dan Tony Bernay, 1999, Women In Power, Perempuan dalam Kekuasaan Politik Jakarta, PT. Gramedia 
Wahyuni, Sri dan Hedwigis Esti R, 2009 Pandangan Publik tentang Keputusan Perempuan dalam Kancah Politik di Indonesia dalam Gender and Politic, Tiara Wacana Yogyakarta

Warren, Karen, 1996, "Ecological Feminist Philosophies An Overview of the Issues, dalam Karen J, Warren (ed), Ecological Feminist Philosophies (Bloomington \& Indianapolis University Press hal xi

Jurnal Perempuan No. 19, Penerbit Yayasan Jurnal Perempuan, Jakarta, 2001

Jurnal Perempuan No 21, Penerbit Yayasan Jurnal Perempuan, Jakarta, 2002

Jurnal Perempuan No 75, Penerbit Yayasan Jurnal Perempuan, Jakarta, 2012
Jurnal Perempuan No 81, Penerbit Yayasan Jurnal Perempuan, Jakarta, 2014

Subono, Nur Iman, (2012), Femocrat: Kritik Feminis dan Representasi Birokrasi, dalam Jurnal Perempuan, Vol. 17, No. 4, Hal 17. Yayasan Jurnal Perempuan, Jakarta.

Sundari, Ayu, (2014), Politik Berbasis Komunitas: Pemberdayaan Perempuan Pemimpin di Yogyakarta, dalam Jurnal Perempuan Vol. 19, No. 2, Hal 133, Yayasan Jurnal Perempuan, Jakarta.

Rahayu, Angger Wiji, (2012), Mitos, Data dan Fakta Perempuan Pemimpin, dalam Jurnal Perempuan, Vol. 17, No. 4, Hal 68. Yayasan Jurnal Perempuan, Jakarta. 